A strain of avian flu that spread through a family in Indonesia, killing seven of the eight people infected, was accumulating mutations as it spread from person to person, according to confidential sequence data seen by Nature. The functional significance of the mutations isn't clear - most of them seem unimportant. But influenza researchers say the finding reiterates the need for sequence data to be made more widely available, if the virus is to be better understood.

The cluster of cases of the deadly H5N1 strain, which occurred earlier this year, is the first in which the World Health Organization (WHO) has admitted that human-to-human transmission was the most likely cause of spread (see Nature 441, 554-555; 2006). Eight members of an extended family in Kubu Sembelang, in north Sumatra, were affected. The first patient, a 37-year-old woman who became ill on 24 April and died on 4 May, is thought to have caught the disease from poultry, then transmitted it to six relatives. One of these, her 10-year-old nephew, who died on 13 May, is thought to have passed the disease to his 32-year-old father (see 'Flu cluster in Indonesia').

Virus isolates from six of the eight family members have been sequenced, but the WHO has not released the data, saying that they belong to Indonesia. Instead, the agency released a statement on 23 May stating that there was "no evidence of genetic reassortment with human or pig influenza viruses

\section{FLU CLUSTER IN INDONESIA}

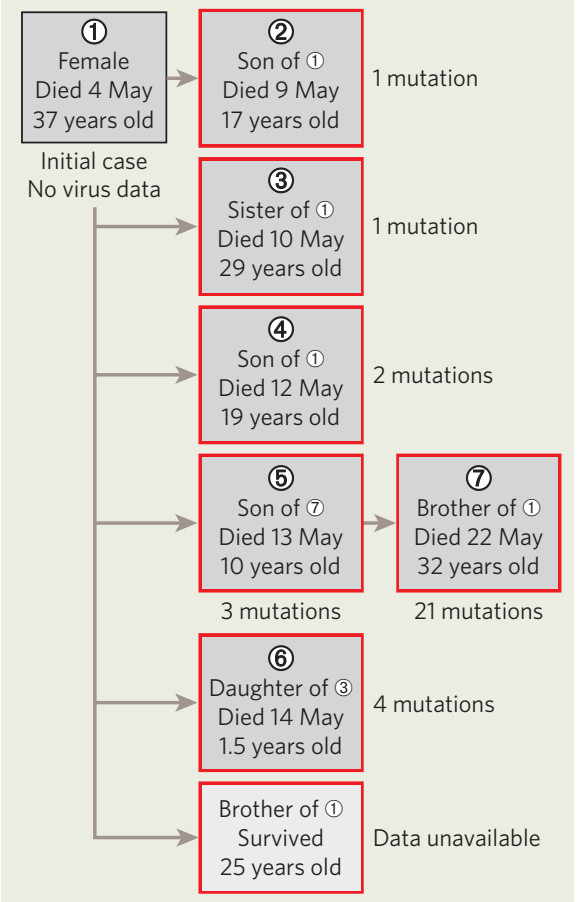

$\rightarrow$ Suspected transmission route

Cases numbered in order of death

Confirmed cases of $\mathrm{H} 5 \mathrm{~N} 1$

and no evidence of significant mutations".

Nature has now obtained more detail on the genetic changes, which suggest that although the WHO statement was not incorrect, plenty more could have been said. Viruses from five of the cases had between one and four mutations each compared with the sequence shared by most of the strains. In the case of the father who is thought to have caught the virus from his son - a second-generation spread - there were twenty-one mutations across seven of the eight flu genes. This suggests that the virus was evolving rapidly as it spread from person to person.

One of the mutations confers resistance to the antiviral drug amantadine, a fact not mentioned in the WHO statement. The data were presented by Malik Pereis, a virologist at the University of Hong Kong, at a closed meeting of around a dozen international experts in animal and human health, held in Jakarta, Indonesia, in late June.

The virus did not evolve into a pandemic strain - the combination of mutations was not even enough to allow it to spread beyond close family. Many of the genetic changes did not result in the use of different amino acids by the virus. And there were no amino-acid changes in key receptor binding sites known to affect pathogenicity and transmissibility.

But experts say they cannot conclude that the changes aren't significant. "It is interesting that we saw all these mutations in viruses that had gone human-to-human," says one scientist who was present at the Jakarta meeting but did not wish to be named because he was commenting on confidential data. "But I don't think anyone knows enough about the H5N1

\title{
Genomics luminary weighs in on US faith debate
}

Is it really possible to combine dedication to science with belief in God? In a new book, prominent US scientist Francis Collins sets out his case for combining a strong religious faith with a zeal for the scientific method. But his views have already sparked debate, with critics suggesting that more talk of religion is the last thing that science needs.

Collins, who directs the National Human Genome Research Institute in Bethesda, Maryland, and headed the Human Genome Project, has never hidden the fact that he is a devout Christian. But he has never spoken quite so publicly about his faith. He says he felt compelled to write his book because the popular debate on faith and science has become dominated by extreme voices, leaving many feeling that there is no way to reconcile religious and scientific views of the world. "Our society is not well served by portraying a future which is either entirely secular or entirely religious in a fundamentalist way," he says.

Collins also hopes the book, The Language of God (Free Press, 2006), will provoke thought in academia, where, he says, the subject of faith isn't exactly popular. "In most academic circles, a discussion of spiritual matters tends to clear the room fairly quickly."

Discussion, Collins suggests, might rectify the misconception that most scientists are atheists. Surveys find that about $40 \%$ of US scientists believe in God, but Collins says that is not reflected in science's public face. That hurts science, he argues, because it drives away curious people who might also be religious believers.

Collins takes a strong stand against some religious beliefs, such as creationism and 'intelligent design'. He considers both to be views that restrict faith to covering gaps in scientific knowledge, leaving it in a tenuous position. Instead, Collins embraces a theology sometimes called theistic evolution, or BioLogos. This embraces the idea that human "A few voices will be shouting out, saying 'wait a minute, this is nonsense'." evolution occurred through natural selection according to God's plan, and that God instilled humanity with certain characteristics, including a 'moral law', that can't be explained by science. 
genome to say how significant that is."

Elodie Ghedin, a genome scientist at the University of Pittsburgh School of Medicine in Pennsylvania, says she's surprised that the virus from the father had so many mutations compared with others in the cluster, apparently arising in just a few days. "I have a hard time believing that the father acquired the virus from his son," she says, adding that the nine mutations in one gene in the father's virus are almost identical to those in viruses isolated from human cases in Thailand and Vietnam in 2004.

One possibility is that the father simply caught a different strain of virus from birds, although other mutations in his virus are similar to those in the strain isolated from his son. Or perhaps the virus from the son reassorted with another flu strain circulating in his father at the time, Ghedin says.

Part of the reason the picture is so unclear, say virologists contacted by Nature, is that the continued withholding of genetic data is hampering study of the virus. None of the sequence data from the Indonesian cluster has been deposited in public databases - access is restricted to a small network of researchers linked to the WHO and the US Centers for Disease Control and Prevention in Atlanta, Georgia.

Ghedin, for example, works on how mutations in one area of a genome can predispose other areas to further changes. She is part of a project started in 2004 to sequence thousands of human and bird-flu strains, but she has little access to H5N1 virus from humans. "Flu researchers don't all look at the data from

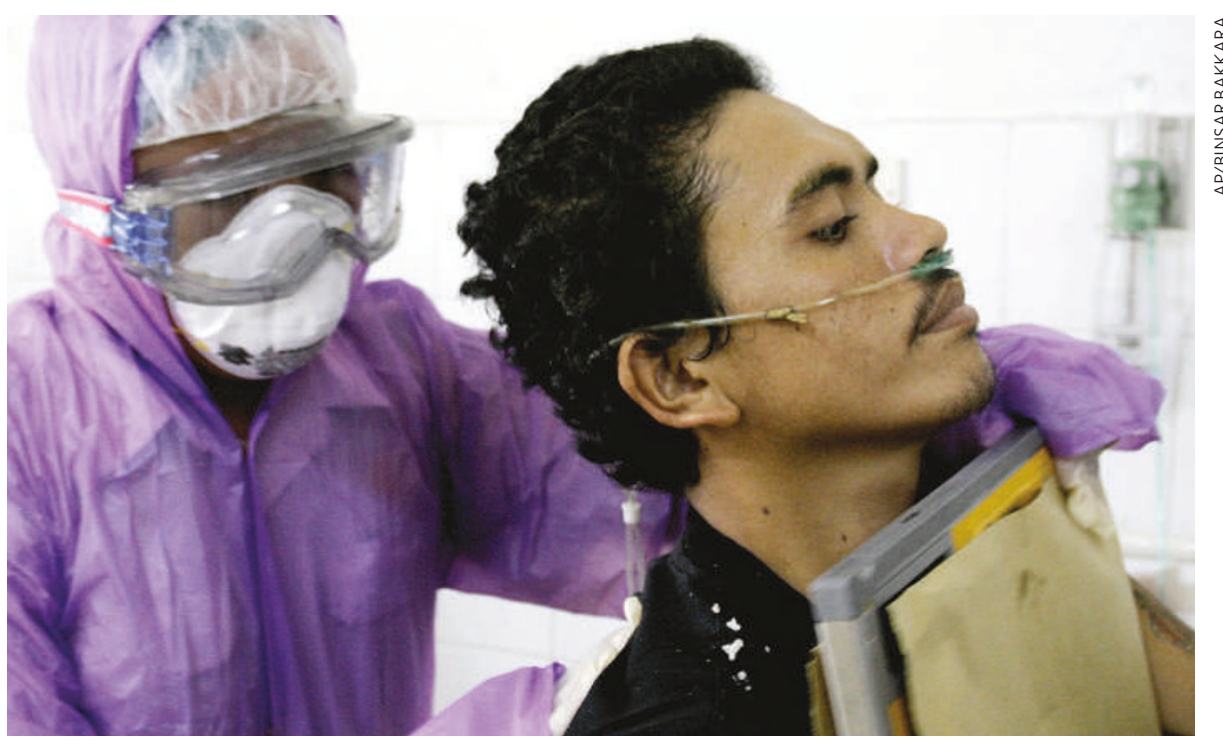

Johannes Ginting is the only survivor of a worrying cluster of bird-flu cases in Indonesia.

the same angle," she says. "The more diverse analyses that are performed, the better we will understand the evolution of this virus."

"If all of the H5N1 isolates were available, there'd be quite a few people focused on under-
se data," agrees David Lipman, director of the US National Center for Biotechnology Information in Bethesda, Maryland.

But Paul Gully, who joined the WHO two months ago as senior adviser to Margaret Chan, head of the agency's pandemic-flu efforts, defends the agency's position. He points out that the WHO's priority is investigating outbreaks, not academic research. And he adds that although calls for more complete genome data and wider sharing of samples are "a valid point", labs are stretched during outbreaks, and don't have the time or resources to do high-quality sequencing.

He agrees that sharing samples with other researchers would allow such work to be done. But he says the WHO must work within the constraints set by its member states - they own the data, and decide whether to share it. "As more countries share data, hopefully that research will get done," he says.

The WHO has not formally asked Indonesia to share the sequences, Gully adds. "We would rather wait and see what Indonesia decides." Declan Butler

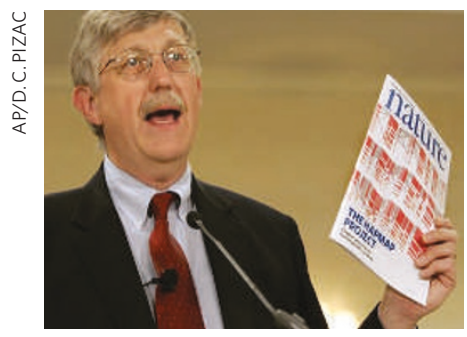

Francis Collins is a devout Christian.

"The moral law is a signpost to a God who cares about us as individuals," Collins says. "God used a mechanism of evolution to create human beings with whom he could have that kind of fellowship."

Many scientists disagree strongly with such arguments. Some suggest that science is on the defensive today - not just in the United States - and that society needs exactly the opposite of what Collins suggests: less talk about faith and more about reason. Religious concerns are largely behind the US law restricting federal funding of stem-cell research, for example. And many feel threatened by the influence of intelligent design in science education.

In the United States, "the default position right now is to assume that religion is perfectly OK", says Paul Myers, a biologist at the University of Minnesota in Morris and author of the popular science blog Pharyngula. "Collins is taking that default position, and while a large majority of scientists will shrug their shoulders, a few voices will be shouting out, saying 'wait a minute, this is nonsense'."

"I cannot see how this could be good for science - supernaturalism is fundamentally anti-scientific," says Richard Dawkins, a biologist from the University of Oxford, UK. "Scientists work hard at trying to understand. Supernaturalism is an evasion of this responsibility. It's a shrug of the shoulders."

Dawkins acknowledges that, particularly in the United States, there might be tactical reasons for trying to get on with religious people. "That is a perfectly reasonable political stance, but it has nothing to do with truth."

Others welcome Collins's book, however. "I think it's helpful when scientists of Francis's prominence speak out on the compatibility of faith and science," says Eugenie Scott, executive director of the National Center for Science Education, a group based in Oakland, California, that lobbies against creationism.

Scott agrees with Collins that so far the harshest voices have achieved most prominence, and that this situation doesn't help either side. "Creationists love quoting Dawkins and Daniel Dennett," she says. "But those individuals don't represent the fairly sizeable proportion of non-theists who are not out to destroy religion." Erika Check 